\title{
CHARACTERIZATION OF COAL SEAMS IN THE ARANTIGA AND SELUANG MINE BENGKULU USING PROXIMATE ANALYSIS DATA
}

\author{
Rafi Maulana ${ }^{1^{*}}$, Ordas Dewanto ${ }^{2}$, A Raka Abriansyah ${ }^{3}$ \\ 1,2Teknik Geofisika Universitas Lampung; Bandar Lampung \\ ${ }^{3}$ PT. Kusuma Raya Utama; Bengkulu
}

Received: 2020, July $27^{\text {th }}$

Accepted: 2020, August 25 ${ }^{\text {th }}$

Keyword:

Coal seam;

Proximate Analysis;

Arantiga;

Seluang.

Corespondent Email: maulanarafi95@gmail.com

How to cite this article: Maulana, R., Dewanto, O., \& Abriansyah, A.R. (2020). Karakterisasi Lapisan Batubara Pada Tambang Arantiga dan Seluang Menggunakan Analisis Data

\begin{abstract}
Abstrak. Indonesia sebagai negara pemilik cadangan batubara cukup besar yang tersebar di wilayah pulau Sumatera dan pulau Kalimantan. Dengan potensi yang sangat besar pada wilayah tersebut perlu adanya suatu penelitian lanjutan untuk dapat mengetahui kualitas dan keunggulan dari sumberdaya batubara guna mengetahui karakteristik secara terinci, maka dilakukannya penelitian di daerah Provinsi Bengkulu dengan cara melakukan pengujian sampel batubara berdasarkan analisis Proksimat untuk mendapatkan hasil kualitas batubara yang akurat dan dapat dilakukan analisis karakteristik batubara pada wilayah tersebut. Diperoleh hasil bahwa, Lapisan batubara pada Tambang Arantiga memiliki nilai rata-rata Inherent Moisture senilai $7.49 \%$, ASH senilai $9.82 \%$, Volatile Matter senilai $40.99 \%$, Fixed Carbon senilai 41.70 $\%$, Total Sulfur senilai $0.34 \%$, Gross Caloric Value senilai $6305 \mathrm{kcal} / \mathrm{kg}$ dan termasuk jenis batubara High Volatile A Bituminous, sedangkan lapisan batubara pada Tambang Seluang memiliki nilai rata-rata Inherent Moisture senilai 2.07 \%, ASH senilai $22.92 \%$, Volatile Matter senilai 20.26 \%, Fixed Carbon senilai 54.78 \%, Total Sulfur senilai $0.55 \%$, Gross Caloric Value senilai $6365 \mathrm{kcal} / \mathrm{kg}$ dan termasuk jenis batubara Medium Volatile Bituminous.
\end{abstract}

Abstract. Indonesia as a country that has ample large coal reserves spread across the Sumatera and Kalimantan islands. The huge potential in the region needs further research to be able to find out the quality and excellence of coal resources in order to know the characteristics in detail, then the research was carried out in the Bengkulu Province area by testing coal sample based on Proximate analysis to obtain accurate coal quality results and analysis of coal characteristics in the area 
Proksimat. Jurnal Geofisika Eksplorasi, 6(3), 197-204.

(c) 2020 JGE (Jurnal Geofisika Eksplorasi). This article is an open access article distributed under the terms and conditions of the Creative Commons Attribution (CC BY NC) can be carried out. The results show that the coal seams in the Arantiga mine have an average value Inherent Moisture is worth $7.49 \%$, ASH is worth $9.82 \%$, Volatile Matter is worth $40.99 \%$, Fixed Carbon is worth $41.70 \%$, Total Sulfur is worth $0.34 \%$, Gross Caloric Value is worth $6305 \mathrm{kcal} / \mathrm{kg}$ and including of High Volatile A Bituminous coal type, while the Seluang mine has an average value Inherent Moisture is worth $2.07 \%$, ASH is worth $22.92 \%$, Volatile Matter is worth $20.26 \%$, Fixed Carbon is worth $54.78 \%$, Total Sulfur is worth $0.55 \%$, Gross Caloric Value is worth $6365 \mathrm{kcal} / \mathrm{kg}$ dan and including of Medium Volatile Bituminous coal type.

\section{PENDAHULUAN}

Indonesia sebagai negara yang memiliki cadangan batubara cukup besar, cadangan tersebut tersebar di Pulau Sumatera dan Pulau Kalimantan. Berdasarkan hal tersebut, maka diperlukan suatu penelitian lanjutan untuk mengetahui kualitas dan karakteristik dari sumberdaya batubara secara terinci.

Batubara merupakan salah satu energi alternatif sebagai pengganti hidrokarbon. Pada Pulau Sumatera cadangan batubara terdapat di beberapa daerah diantaranya adalah di Provinsi Bengkulu yang terletak pada Cekungan Bengkulu atau dikenal sebagai cekungan busur muka yang berlokasi di bagian barat daya Pulau Sumatera.

Cekungan Bengkulu berumur OligosenMiosen yang tersusun oleh batuan silisiklastik, batubara dan karbonat serta dapat dijumpai dalam batuan sedimen Formasi Lemau yang berumur Miosen Tengah sampai dengan Miosen Akhir, seperti yang teramati di daerah Ketaun, Bengkulu dan Seluma. Pada daerah Bengkulu memiliki ketebalan lapisan batubara berkisar antara 100 - $350 \mathrm{~cm}$ (Heryanto \& Suyoko, 2007).

Lapisan batubara pada daerah Bengkulu memiliki karakteristik warna hitam mengkilap dengan gores warna hitam dan batubara terbentuk pada lingkungan yang relatif lebih ke arah darat atau upper delta plain (Heryanto \& Suyoko, 2007). Batubara merupakan energi alternatif yang potensial selain hidrokarbon yang dapat digunakan sebagai prospek sumber energi cadangan terutama untuk pembangkit listrik serta kepentingan bahan bakar dan kebutuhan bahan baku industri.

Pemanfaatan batubara pada industri terutama untuk pembangkit listrik, industri semen dan pengolahan logam perlu diketahui kualitas dan karakteristiknya melalui analisis proksimat, seperti kandungan air, kandungan zat terbang, kandungan abu dan kandungan karbon (Lestari S et al., 2017).

Berdasarkan hal tersebut, perlu dilakukannya penelitian di daerah Provinsi Bengkulu dengan cara melakukan pengujian sampel batubara yaitu analisis proksimat yang bertujuan untuk mendapatkan hasil kualitas yang akurat dari batubara tersebut dan dapat dilakukan analisis karakteristik batubara wilayah tesebut.

\section{TINJAUAN PUSTAKA}

Daerah penelitian ini berada di Kecamatan Taba Penanjung, Kabupaten Bengkulu Tengah, Provinsi Bengkulu. Cekungan Bengkulu (Gambar 1) merupakan cekungan busur muka berlokasi di bagian barat daya Pulau Sumatera. Cekungan Bengkulu berumur Oligosen sampai Miosen yang tersusun oleh batuan silisiklastik, batubara, dan batuan karbonat (Gafoer et al., 1992). Batubara dapat dijumpai dalam batuan sedimen Formasi Lemau yang berumur pada Miosen Tengah sampai dengan Akhir.

Formasi Lemau tersusun oleh satuan batu pasir gampingan, batu lanau gampingan, 
breksi tersisipkan batu gamping dan batu lempung. Formasi Lemau terendapkan tidak selaras diatas Formasi Seblat, berdasarkan fosil-fosil yang ditemukan menunjukkan bahwa Formasi Lemau berumur Miosen Tengah sampai Miosen Akhir serta terendapkan pada lingkungan laut dangkal.

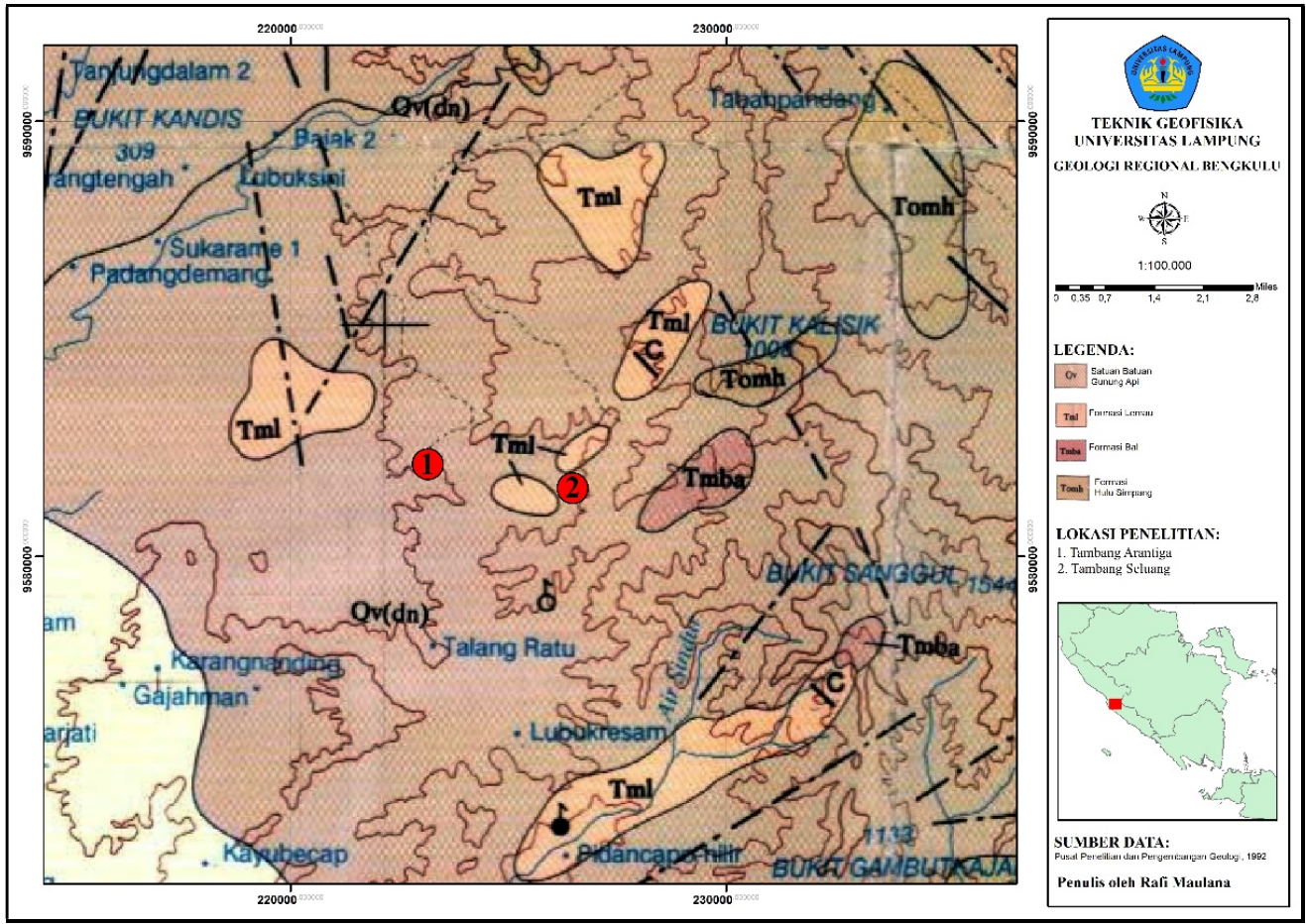

Gambar 1. Peta Geologi Penelitian (penyederhanaan dari Gafoer et al., 1992).

Pengendapan batubara termasuk dalam Formasi Lemau yang berumur Miosen Tengah (Gafoer et al., 1992) dan terbentuk selama fase regresi bersamaan dengan proses orogenesa yang disebut Syn-Orogenic Regresive Phase Depositional, batubara terendapkan di lingkungan progradasi delta menuju ke arah barat (Koesoemadinata, 2002).

\section{TEORI DASAR}

\subsection{Pengertian Batubara}

Batubara adalah batuan sedimen yang dapat terbakar, berasal dari tumbuhantumbuhan (komposisi utamanya adalah karbon, hidrogen dan oksigen), berwarna coklat hinggga hitam dan saat terjadi proses kimia dan fisika dapat mengakibatkan kandungan karbonnya meningkat.
Batubara terbentuk dari sisa tumbuhtumbuhan yang mengalami proses humifikasi, batubara memiliki warna coklat hingga hitam, setelah itu terjadi proses fisika dan kimia sehingga mengakibatkan pengayaan kandungan karbonnya dan berlangsung selama jutaan tahun (Anggayana, 2002).

\subsection{Proses Pembentukan Batubara}

Batubara berasal dari tumbuh-tumbuan yang terendapkan di bawah permukaan bumi dan terbentuk karena adanya proses geologi dan kimiawi di dalamnya sehingga terbentuklah endapan batubara. Komposisi utama dari batubara yaitu terdiri dari karbon dan hidrogen, selain itu juga terdapat kandungan mineral nitrogen.

Vegetasi tumbuhan berada pada hutan lebat di daerah lahan basah dataran rendah 
yang mati kemudian tertimbun oleh tanah atau material yang berada diatasnya dan terendapkan hingga terbentuklah Gambut (Peat). Hingga mengalami proses kompresi dari lapisan sedimen yang berada di atasnya serta mengalami kenaikan temperatur akibat geothermal gradient.

Mengakibatkan terjadinya lignit (brown coal) karena banyaknya unsur oksigen dan hidrogen yang terlepas sehingga unsur karbon bertambah. Proses terbentuknya batubara terjadi dua tahap yaitu penggambutan dan pembatubaraan, secara singkat pembentukan batubara diawali dari proses konversi yang lambat dari vegetasi mati menjadi batubara disebut juga carbonitation, serta terjadinya kompresi terus menerus dan mengalami kenaikan temperatur terbentuklah batubara sub-bituminus dan bituminus.

Kompresi terjadi terus menerus dan diiringi bertambahnya temperatur sehingga moisture sangat sedikit serta unsur karbon menigkat menjadikan batubara ke tingkat batubara yang tertinggi yaitu antrasit (Cook, 1982).

\subsection{Lokasi Terbentuknya Batubara}

Berdasarkan lokasi pemebentukan batubara di kenal dua macam teori pembentukannya yaitu teori insitu dan teori drift, sebagai berikut:

\section{Teori Insitu}

Teori ini menyatakan bahwa bahan-bahan pembentuk lapisan batubara, terjadi di tempat vegetasi tumbuh-tumbuhan itu berada dan berasal, tumbuh-tumbuhan yang telah mati tersebut segera tertutup oleh lapisan sedimen dan belum mengalami proses transportasi hingga mengalami proses coalification. Jenis batubara yang terbentuk memiliki kualitas batubaranya lebih baik dikarenakan kadar abunya yang relatif kecil serta memiliki pesebaran yang luas dan merata

\section{Teori Drift.}

Teori ini menyatakan bahwa bahan-bahan pembentuk lapisan batubara terjadi di tempat yang berbeda dengan tempat vegetasi tumbuhtumbuhan tersebut semula hidup. Tumbuhtumbuhan yang telah mati mengalami proses transportasi dan berakumulasi di suatu tempat, segera tertutup oleh lapisan sedimen hingga mengalami proses coalification. Jenis batubara yang terbentuk memiliki kualitas batubaranya kurang baik dikarenakan banyak mengandung material pengotor yang terangkut bersamaan selama proses transportasi dari tempat tumbuh-tumbuhan berasal ke tempat sedimentasi serta pesebaran tidak luas, dan dapat di jumpai di beberapa tempat (Sukandarrumidi, 2008).

\subsection{Analisis Kualitas Batubara}

Kualitas batubara adalah suatu sifat fisika dan kimia dari batubara yang dapat mempengaruhi nilai potensi untuk pemafaatannya dan kegunaannya. Kualitas batubara dapat ditentukan oleh maseral dan mineral matter yang terkandung didalamnya serta dipengaruhi pula oleh derajat coalification. Untuk dapat menentukan kualitas batubara, maka dilakukan analisis kimia pada batubara diantaranya dengan memperhatikan sejumlah parameterparameter kualitas yang ingin dihasilkan dari analisis kimia dan pengujian pada laboratorium. Analisis kimia batubara terdiri dari analisis ultimat dan analisis proksimat.

Terdapat 2 metode analisa yang umumnya digunakan untuk mengetahui kualitas batubara yaitu air-dried based (adb) dan as received (ar). Analisis air-dried base (adb) adalah melakukan analisis sampel batubara dalam keadaan kelembaban udara sekitarnya. Sampel batubara akan didiamkan dalam beberapa waktu sehingga kandungan moisture berkurang. Sedangkan analisis as recievied (ar) adalah melakukan analisis sampel batubara dengan dilakukan segera ketika sampel tersebut baru diterima di laboratorium sehingga kandungan moisture saat 
pengambilan sampel batubara sangat berpengaruh terhadap nilai kualitasnya.

Perbedaan mendasar pada kedua analisis ini dipengaruhi oleh Total Moisture (TM). Kandungan Total Moisture (TM) yang bernilai tinggi dapat menurunkan kualitas batubara, yaitu pada nilai Calorie Value (CV). Apabila nilai Total Moisture (TM) meningkat maka nilai Calorie Value (CV) pun akan turun, sebaliknya apabila Total Moisture (TM) dapat dijaga atau diturunkan maka nilai Calorie Value (CV) akan relatif stabil bahkan akan meningkat.

\subsection{Klasifikasi Batubara ASTM}

Klasifikasi batubara oleh American Society for Testing and Materials (ASTM) dibuat berdasarkan jumlah karbon padat dan nilai karbon dalam basis dry mineral matter free (dmmf). Untuk mengubah basis air dried (adb) menjadi dry mineral matter free (dmmf) maka digunakan Parr Formulas (Wood et al., 1983), yaitu:

$$
\begin{aligned}
& F C_{(\mathrm{dmmf})}=\frac{\{(F C-0.15 \times S) 100\}}{[100-(M+1.08 \times A+0.55 \times S)]} \\
& V M_{(\mathrm{dmmf})}=100-F C_{(\mathrm{dmmf}]}
\end{aligned}
$$

Keterangan:

$$
\begin{array}{ll}
\text { FC } & =\% \text { Karbon Padat }_{(\mathrm{adb})} \\
\mathrm{VM} & =\% \text { Zat Terbang }_{(\mathrm{adb})} \\
\mathrm{M} & =\% \text { Kadar Air }_{(\mathrm{adb})} \\
\mathrm{A} & =\% \text { Abu }_{(\mathrm{adb})} \\
\mathrm{S} & =\% \text { Sulfur }_{(\mathrm{adb})} \\
\text { Btu } & =1,8185^{\star} \mathrm{CV}_{(\mathrm{adb})}
\end{array}
$$

Istilah-istilah "Basis":

As Received disingkat : ar

Air Dried disingkat: ad atau adb

Dry disingkat $\quad: \mathrm{db}$

Dry Ash Free disingkat : daf

Dry Mineral Matter

Free disingkat $\quad: \mathrm{dmmf}$
Harus dicantumkan setiap menuliskan Nilai Parameter Kualitas (Sukandarrumidi, 2008).

\subsection{Klasifikasi Maseral Batubara}

Maseral merupakan bagian terkecil dari batubara yang dapat teramati dengan menggunakan mikroskop. Maseral dikelompokan berdasarkan bagian tumbuhan menjadi tiga grup:

1. Vitrinit

Vitrinit adalah hasil dari proses pembatubaraan materi humic yang berasal dari selulosa $\left(\mathrm{C}_{6} \mathrm{H}_{10} \mathrm{O}\right)$ dan lignin dinding sel tumbuhan yang mengandung serat kayu (woody tissue) seperti batang, akar, daun. Kelompok ini mengandung persentasi unsur hidrogen dan zat terbang yang berada diantara kelompok Inertinit dan kelompok liptinit. Mempunyai berat jenis $1,3-1,8 \mathrm{gr} / \mathrm{cc}$ dan kandungan oksigen yang tinggi serta kandungan volatile matter sekitar 35,75\%.

\section{Liptinit (Exinit)}

Liptinit berasal dari sisa tumbuhan atau dari jenis tanaman tingkat rendah seperti serbuk sari (pollen), spora, gangang (algae), kutikula dan getah tanaman (resin)(Taylor et al., 1998). Liptinite mempunyai berat jenis 1,0 - 1,3 gr/cc dan kandungan hidrogen yang paling tinggi dibanding dengan maseral lain, sedangkan kandungan volatile matter sekitar $66 \%$.

3. Inertinit

Inertinit diduga berasal dari tumbuhan yang telah terbakar dan sebagian dari hasil proses oksidasi kelompok maseral lainnya yang disebabkan oleh bakteri dan jamur. Kelompok ini mengandung persentasi unsur hidrogen paling rendah dari kelompok lainnya dan di antara kelompok maseral lainnya karakteristik utama kelompok ini adalah reflektansi yang tinggi. Inertinite mempunyai berat jenis 1,5 $2,0 \mathrm{gr} / \mathrm{cc}$ dan kandungan karbon yang paling tinggi dibanding maseral lain serta kandungan 
volatile matter sekitar 22,9\% (Kentucky Geological Survey, 2006).

\section{METODE PENELITIAN}

Adapun pada penelitian ini metode yang dilakukan adalah metode analisis dengan tujuan mengkarakterisasi batubara pada area Tambang Arantiga dan Tambang Seluang. Untuk mendapatkan data sebelumnya dilakukan studi literatur dengan cara meengumpulkan referensi dari penelitian terdahulu, selanjutnya observasi lapangan hal ini untuk mengetahui kondisi geologi daerah penelitian dan selanjutnya dilakukan pengambilan sampel batubara dengan masingmasing daerah penelitian yaitu 5 sampel batubara.

Setelah diperoleh sampel dilakukan pengujian laboratorium di Laboratorium PT. Sucofindo yang terdiri dari analisis proksimat, kandungan sulfur dan nilai kalori (calorific value). Analisis proksimat dilakukan untuk mengetahui nilai kadar air (moisture), kandungan zat terbang (volatile matter), kadar abu (ash) dan kadar karbon (fixed carbon).
Dari data proksimat hasil pengujian laboratorium sampel batubara pada area Tambang Arantiga dan Tambang Seluang tersebut dianalisis dan diinterpretasikan dengan klasifikasi ASTM untuk diperoleh karakteristik lapisan batubara pada daerah penelitian.

\section{HASIL DAN PEMBAHASAN}

Berdasarkan hasil pengujian sampel batubara Tambang Arantiga dapat dilihat pada Tabel 1 diperoleh nilai rata-rata Inherent Moisture senilai 7.49\%, ASH senilai 9.82\%, Volatile Matter senilai 40.99\%, Fixed Carbon senilai $41.70 \%$, Total Sulfur senilai $0.34 \%$, Gross Caloric Value senilai $6305 \mathrm{kcal} / \mathrm{kg}$, sedangkan sampel batubara Tambang Seluang dapat dilihat pada Tabel 2 diperolehi nilai ratarata Inherent Moisture senilai 2.07\%, ASH senilai 22.92\%, Volatile Matter senilai 20.26\%, Fixed Carbon senilai 54.78\%, Total Sulfur senilai 0.55\%, Gross Caloric Value senilai 6365 $\mathrm{kcal} / \mathrm{kg}$.

Tabel 1. Hasil Analisis Proksimat Tambang Arantiga

\begin{tabular}{|c|c|c|c|c|c|c|}
\hline \multirow{4}{*}{$\begin{array}{l}\text { IDENTIFIKASI } \\
\text { SAMPEL }\end{array}$} & \multicolumn{6}{|c|}{ PARAMETER } \\
\hline & IM & ASH & VM & FC & TS & GCV \\
\hline & $(\%)$ & (\%) & (\%) & (\%) & $(\%)$ & (kcal/kg) \\
\hline & $\mathbf{a d b}$ & $\mathbf{a d b}$ & $\mathbf{a d b}$ & $\mathbf{a d b}$ & $\mathbf{a d b}$ & $\mathbf{a d b}$ \\
\hline KRU A3_150 & 7,32 & 9,23 & 40,55 & 42,90 & 0,36 & 6350 \\
\hline KRU A3_151 & 7,76 & 9,05 & 42,81 & 40,38 & 0,34 & 6327 \\
\hline KRU A3_152 & 7,44 & 9,85 & 40,09 & 42,62 & 0,33 & 6294 \\
\hline KRU A3_153 & 7,63 & 9,95 & 38,66 & 43,76 & 0,38 & 6290 \\
\hline KRU A3_156 & 7,07 & 11,29 & 40,33 & 41,31 & 0,35 & 6266 \\
\hline RATA-RATA & 7,49 & 9,82 & 40,99 & 41,70 & 0,34 & 6305 \\
\hline
\end{tabular}

Batubara di Tambang Arantiga memiliki nilai rata-rata kalori batubara senilai 6305 $\mathrm{kcal} / \mathrm{kg}$ sedangkan Tambang Seluang memiliki nilai rata-rata kalori batubara yaitu senilai 6365 $\mathrm{kcal} / \mathrm{kg}$. Dilihat dari nilai tersebut bahwa kualitas batubara pada Tambang Seluang lebih baik dibandingkan dengan batubara pada Tambang Arantiga namun kedua batubara pada daerah tersebut dikategorikan baik dan bernilai ekonomis dilihat dari nilai kalori batubara termasuk dalam kategori kelas tinggi (High) yaitu bernilai antara $6100-7100$ $(\mathrm{kcal} / \mathrm{kg}$, adb). Sehingga diperoleh hasil bahwa kualitas batubara dikatakan memiliki kualitas baik. 
Dapat dilihat pada Tabel 3. Tambang Arantiga memiliki karakterisasi maseral dominan Vitrinite yaitu kandungan zat terbang (Volatile Matter) senilai $40.99 \%$ dengan kategori tinggi karena nilai $\mathrm{VM}>35.75 \%$ -
$<66 \%$, kandungan karbon (Fixed Carbon) senilai $41.70 \%$ dan total sulfur senilai $0.34 \%$ dengan kategori rendah karena kandungan sulfur $\mathrm{S}<0.6 \%$.

Tabel 2. Hasil Analisis Proksimat Tambang Seluang

\begin{tabular}{|c|c|c|c|c|c|c|}
\hline \multirow{4}{*}{$\begin{array}{l}\text { IDENTIFIKASI } \\
\text { SAMPEL }\end{array}$} & \multicolumn{6}{|c|}{ PARAMETER } \\
\hline & IM & ASH & VM & FC & TS & GCV \\
\hline & $(\%)$ & $(\%)$ & $(\%)$ & $(\%)$ & $(\%)$ & (kcal/kg) \\
\hline & adb & $\mathbf{a d b}$ & adb & $\mathbf{a d b}$ & $\mathbf{a d b}$ & Adb \\
\hline KRU SL_111 & 2,16 & 25,65 & 18,57 & 53,62 & 0,58 & 5960 \\
\hline KRU SL_112 & 2,20 & 26,62 & 18,97 & 52,21 & 0,55 & 5872 \\
\hline KRU SL_149 & 1,94 & 19,96 & 20,89 & 57,21 & 0,54 & 6521 \\
\hline KRU SL_154 & 1,85 & 16,99 & 22,37 & 58,79 & 0,51 & 6772 \\
\hline KRU SL_155 & 1,96 & 17,97 & 23,09 & 57,16 & 0,53 & 6702 \\
\hline RATA-RATA & 2,07 & 22,92 & 20,26 & 54,78 & 0,55 & 6365 \\
\hline
\end{tabular}

Tabel 3. Karakteristik Batubara

\begin{tabular}{cccccc}
\hline & & \multicolumn{3}{c}{ PARAMETER } & \\
\cline { 3 - 5 } $\begin{array}{c}\text { IDENTIFIKASI } \\
\text { SAMPEL }\end{array}$ & $\begin{array}{c}\text { LOKASI } \\
\text { TAMBANG }\end{array}$ & FC (\%) & VM (\%) & $\begin{array}{c}\text { GCV } \\
(\mathbf{K c a l} / \mathbf{k g})\end{array}$ & JENIS BATUBARA \\
& & $\mathbf{d m m f}$ & $\mathbf{d m m f}$ & $\mathbf{a d b}$ & \\
\hline KRU A3 & ARANTIGA & 50,97 & 49,03 & 6305 & $\begin{array}{c}\text { High Volattile A } \\
\text { Bituminous }\end{array}$ \\
& & & & & Medium Volattile \\
KRU SL & SELUANG & 75,05 & 24,95 & 6365 & Bituminous \\
\hline
\end{tabular}

Menurut klasifikasi ASTM (American Society for Testing and Material) untuk mengetahui jenis batubara pada lokasi peneilitian yang menghasilkan nilai $\mathrm{FC}_{(\mathrm{dmmf})}$ senilai $50.97 \%$ dan nilai $\mathrm{VM}_{(\mathrm{dmmf})}$ senilai $49.03 \%$ temasuk jenis batubara High Volatile $A$ Bituminous.

Sedangkan batubara pada Tambang Seluang memiliki karakterisasi maseral dominan Inertinite yaitu kandungan zat terbang (Volatile Matter) senilai 20.26\% dengan kategori rendah karena nilai $\mathrm{VM}<$ 22.9\%, kandungan karbon (Fixed Carbon) senilai $54.78 \%$ dan total sulfur senilai $0.55 \%$ dengan kategori rendah karena kandungan sulfur $\mathrm{S}<0.6 \%$.

Menurut klasifikasi ASTM (American Society for Testing and Material) untuk mengetahui jenis batubara pada lokasi peneilitian yang menghasilkan nilai $\mathrm{FC}_{(\mathrm{dmm})}$ senilai $75.05 \%$ dan nilai $\mathrm{VM}_{(\mathrm{dmmf})}$ senilai $24.95 \%$ termasuk jenis batubara Medium Volatile Bituminous.

Pada penelitian selanjutnya agar dapat menggunakan data Logging dan Coring pada saat pengeboran agar memiliki data yang lebih akurat dan menunjang dalam menentukan kualitas batubara untuk 
pemanfaatan batubara serta tidak terkontaminaasi dengan material lain.

\section{KESIMPULAN}

Adapun kesimpulan yang didapat dari penelitian ini adalah sebagai berikut:

Lapisan batubara pada Tambang Arantiga memiliki nilai rata-rata Inherent Moisture senilai $7.49 \%$, ASH senilai $9.82 \%$, Volatile Matter senilai 40.99 \%, Fixed Carbon senilai $41.70 \%$, Total Sulfur senilai $0.34 \%$, Gross Caloric Value senilai $6305 \mathrm{kcal} / \mathrm{kg}$, sedangkan lapisan batubara pada Tambang Seluang memiliki nilai rata-rata Inherent Moisture senilai $2.07 \%$, ASH senilai $22.92 \%$, Volatile Matter senilai $20.26 \%$, Fixed Carbon senilai $54.78 \%$, Total Sulfur senilai $0.55 \%$, Gross Caloric Value senilai $6365 \mathrm{kcal} / \mathrm{kg}$.

Batubara pada Tambang Arantiga memiliki karakteristik maseral dominan Vitrinite yaitu dilihat dari kandungan zat terbang (Volatile Matter) senilai 40.99 \% dengan kategori tinggi, kandungan karbon (Fixed Carbon) senilai 41.70 dan total sulfur senilai $0.34 \%$ dengan kategori rendah, sedangkan batubara pada Tambang Seluang memiliki karakteristik maseral dominan Inertinite yaitu dilihat dari kandungan zat terbang (Volatile Matter) senilai $20.26 \%$ dengan kategori rendah, kandungan karbon (Fixed Carbon) senilai $54.78 \%$ dan total sulfur senilai $0.55 \%$ dengan kategori rendah.

Batubara pada Tambang Arantiga memiliki nilai $\mathrm{FC}_{(\mathrm{dmmf})}$ senilai $50.97 \%$ dan nilai $\mathrm{VM}_{(\mathrm{dmmf})}$ senilai $49.03 \%$ temasuk jenis batubara High Volatile A Bituminous sedangkan batubara pada Tambang Seluang memiliki nilai $\mathrm{FC}_{(\mathrm{dmm})}$ senilai $75.05 \%$ dan $\mathrm{VM}_{(\mathrm{dmmf})}$ senilai $24.95 \%$ termasuk jenis batubara Medium Volatile Bituminous.

\section{UCAPAN TERIMA KASIH}

Penulis mengucapkan terima kasih kepada PT. Kusuma Raya Utama Bengkulu untuk kesempatan dan izin akses data pada penelitian ini serta semua pihak yang telah memberikan saran dan dukungan terhadap penelitian ini.

\section{DAFTAR PUSTAKA}

Anggayana, K. (2002). Genesa Batubara. Departemen Teknik Pertambangan, FIKTM. Institut Teknologi Bandung.

Cook, A. C. (1982). The Origin and Petrology of Organic Matter in Coals, Oil Shales and Petroleum Source-Rock. Geology Department, The University of Wollongong.

Gafoer, S., Amin, T. C., \& Pardede, R. (1992). Geologi Lembar Bengkulu, Sumatera Skala 1:250.000. Pusat Penelitian dan Pengembangan Geologi.

Heryanto, R., \& Suyoko, S. (2007). Karakteristik batubara di Cekungan Bengkulu. Indonesian Journal on Geoscience, 2(4), 247-259. https://doi.org/10.17014/ijog.vol2no4.20075

Kentucky Geological Survey. (2006). Identification of Coal Components. University of Kentucky. http://www.uky.edu/KGS/coal/coalcomp.htm

Koesoemadinata, R. P. (2002). Outline of Tertiary Coal Basins of Indonesia. Sedimentology Newsletter 17/I/2002. The Indonesian Sedimentologist Forum, Indonesian Association of Geologist, 2-13.

Lestari S, D., Asy'ari, M., \& Hidayatullah, R. (2017). Geokimia Batubara untuk Beberapa Industri. Jurnal Poros Teknik, 8(1), 48-54. https://doi.org/doi:10.31961/porosteknik.v8i1.3 81

Sukandarrumidi. (2008). Batubara dan Gambut. Gajah Mada University Press.

Taylor, G. H., Teichmüller, M., Davis, A., Diessel, C. F. K., Littke, R., \& Robert, P. (1998). Organic Petrology. Gebrüder Borntraeger.

Wood, G. H., Kehn, T. M., Carter, M. D., \& Culbertson, W. C. (1983). Coal Resource Classification System of the U.S. Geological Survey. U.S. Geological Survey. 